\title{
Marketing Politik di Media dan Softening News Gibran Rakabuming Raka dalam Pemilihan Wali Kota Solo
}

\author{
Jeani Riyanti \\ Universitas Indonesa \\ Email: Jeani.riyantiii@gmail.com \\ *corresponding author
}

Keywords:

regional election 2020, local election, political marketing, softening news.

\section{Kata Kunci:}

pilkada 2020, pemilihan kepala daerah, marketing politik, softening news.

\begin{abstract}
The fourth Simultaneous Regional Election, or Pilkada, will be held in December 2020. However, the future-elected-candidate in simultaneous Regional Election will only have a shorter period of time, but many candidates with various backgrounds might enrol during this election. One of the candidates might be Gibran Rakabuming Raka, who will join election as Mayor in Solo. Gibran is the eldest son of Presiden Indonesia, Joko Widodo. We could find pros and cons during his contestation. Gibran had been enrolled as a member of Partai Demokrasi Indonesia Perjuangan (PDIP) as his political vehicle to win the election. PDIP itself is open for any possibilities that want to be regional leaders from PDIP. PDIP had not been decided yet on the candidate who will compete for regional election. Nevertheless, Gibran has been preparing his strategies to be a candidate from PDIP for the Regional Election in Solo. A candidate or political party applied political marketing to achieve $\mathrm{him} /$ her/their goal, which is winning the election. Related to the oriented party concept from Lees-Marshment, Gibran tried to apply value from PDIP. His public appearance in the media and activity of blusukan are carried out so will be in line with the value of PDIP. Besides news coverage of pro-cons of the election, there are many softening news about Gibran instead of his working program for the election.
\end{abstract}

\begin{abstract}
ABSTRAK
Pilkada serentak keempat akan diselenggarakan pada Desember 2020. Walaupun masa jabatan kepala daerah terpilih nantinya hanya memiliki waktu singkat, namun berbagai kalangan dengan beragam latar belakang turut serta dalam persaingan ini. Salah satunya adalah Gibran Rakabuming Raka. Gibran merupakan anak pertama dari Presiden Indonesia saat ini, Joko Widodo. Pro dan kontra bermunculan dari pencalonan Gibran. Namun, Gibran tetap maju dalam bursa bakal calon Wali Kota Solo. Gibran sendiri telah mendaftarkan diri sebagai anggota dari Partai Demokrasi Indonesia Perjuangan (PDIP) sebagai kendaraan politik untuk meraih kekuasaan. PDIP belum memutuskan calonnya untuk bersaing dalam pemilihan Wali Kota Solo. Gibran tetap menjalankan strategi politiknya agar menjadi kandidat dari PDIP untuk mengikuti Pemilihan Kepala Daerah di Solo. Marketing politik dilakukan untuk meraih tujuan yaitu memenangkan pemilihan. Dikaitkan dengan pola partai politik LeesMarshment, Gibran menjalankan nilai yang dimiliki oleh PDIP. Perubahan sikap dengan media dan kegiatan blusukan dilakukan oleh Gibran agar sesuai dengan nilai partai. Selain pemberitaan Gibran terkait dengan pro dan kontra pencalonannya, pemberitaan yang bersifat softening news banyak ditulis oleh media dibandingkan dengan program kerja jika ia terpilih sebagai Wali Kota.
\end{abstract}




\section{PENDAHULUAN}

Setelah berakhirnya euforia Pemilu 2019, di tahun 2020 ini Komisi Pemilihan Umum (KPU) Republik Indonesia telah mempersiapkan program dan tahapan pelaksanaan Pemilihan Kepala Daerah (Pilkada) yang diselenggarakan serentak. Pilkada 2020 mendatang untuk memilih kepala daerah, yaitu Gubernur, Wali Kota dan Bupati. Tahapan, program dan jadwal Pilkada serentak ini diatur dalam Peraturan Komisi Pemilihan Umum (PKPU) No. 19 Tahun 2019. Seperti yang dijelaskan dalam Pasal 1, KPU RI memiliki wewenang dalam membuat aturan Pilkada sedangkan pelaksanaan Pilkada menjadi wewenang KPU Daerah, baik KPU Provinsi atau KPU Kabupaten/Kota (Peraturan KPU No 15 Tahun 2019, 2019).

Pilkada serentak sendiri bukan pertama kali dilaksanakan di Indonesia. Beberapa Provinsi, Kabupaten/Kota telah melaksanakan Pilkada serentak tahun 2015. Pemilu berikutnya di tahun 2016 dan 2018. Walaupun masa kepemimpinan kepala daerah sama, yaitu lima tahun, namun perbedaan ini berdasarkan AMJ (Akhir Masa Jabatan) yang berbeda-beda. Pilkada 2015 dilaksanakan untuk kepala daerah dan wakil daerah yang memiliki AMJ pada tahun 2015 dan semester pertama 2016 (Ferri, 2015). Pilkada serentak 2016 untuk kepala daerah yang berakhir masa jabatan di semester kedua tahun 2016 dan kepala daerah yang berakhir pada tahun 2017. Sedangkan kepada daerah yang berakhir masa jabatan di tahun 2018 dan 2019, dilaksanakan Pilkada serentak tahun Juni 2018.

Pilkada 2020 untuk memilih kepala daerah yang berakhir masa jabatan di tahun 2020 dan 2021. Namun begitu, kepala daerah yang dipilih melalui Pilkada 2020 memiliki masa kepemimpinan kurang dari 5 tahun karena pelaksanaan Pilkada serentak dengan Pemilu Legislatif dan Pemilihan Presiden di Tahun 2024. Pilkada 2020 akan dilaksanakan serentak di 270 daerah, 9 Provinsi, 224 Kabupaten dan 37 Kota. Awalnya Pilkada 2020 ini hanya dilaksanakan di 269 daerah namun Pilkada di Kota Makassar dilaksanakan ulang di tahun 2020 mendatang (Ini 270 Daerah Yang Gelar Pilkada Serentak 2020, 2019). Salah satu dari Pilkada 2020 yang menjadi perhatian adalah Pemilihan Wali Kota Solo, yang diikuti oleh anak dari Presiden Joko Widodo, Gibran Rakabumi Raka.

Pilkada serentak pada awalnya akan dilaksanakan pada tanggal 23 September 2020, namun karena pandemi yang sedang terjadi maka Pilkada serentak dilaksanakan pada 9 Desember 2020 (Peraturan Komisi Pemilihan Umum No. 5 Tahun 2020, 2020). Menurut Peraturan KPU No 15 Tahun 2019, salah satu tahapan Pilkada adalah penetapan calon pasangan kepala daerah. Pendaftaran pasangan Walikota dan Wakil Wali Kota serta Bupati dan Wakil Bupati akan dilaksanakan pada minggu pertama Bulan Maret 2020 (Kemendagri, 2019). Untuk mengikuti Pilkada, pasangan calon Gubernur atau Bupati maupun Wali Kota dapat dicalonkan oleh partai politik atau perseorangan. Walaupun bukan anggota partai politik sebelumnya, namun Gibran Rakabuming Raka atau Gibran mendaftarkan diri sebagai bakal calon Wali Kota Solo melalui Partai Demokrasi Indonesia Perjuangan (PDIP). Selain Gibran, terdapat Achmad Purnomo dan Iwan Triyatno yang menjadi bakal calon Wali Kota Solo dari PDIP. Achmad Purnomo sendiri didukung oleh Ketua Dewan Pimpinan Cabang (DPC) PDIP sekaligus Wali Kota Solo saat ini, FX Hadi Rudyatmo (CNN, 2019). Sikap dari Dewan Pimpinan Pusat (DPP) PDIP masih terbuka terhadap pencalonan yang ada, termasuk Gibran. DPP PDIP masih melakukan fit and proper test terhadap kandidat yang ada. Nantinya Ketua PDIP, Megawati Soekarno Putri, yang menentukan calon Wali Kota Solo dari PDIP. Namun begitu, hasil survey yang dilakukan oleh Median pada tanggal 3-9 Desember 2019, nama Gibran dan Purnomo menjadi dua nama yang memiliki popularitas paling tinggi, yaitu Purnomo dan Gibran (CNN, 2019).

Pencalonan Gibran sebagai Wali Kota Solo memunculkan pro dan kontra. Sejak ayahnya menjadi Presiden RI di tahun 2014, sikap Gibran di depan media cukup menjadi perhatian. Dibandingkan dengan saudara-saudaranya yang lain, Gibran cukup kaku di media. Bahasa tubuh dan sikap Gibran seolah dianggap kurang bersahabat dan sombong. Pose mengangkat dagu sering terlihat ketika di depan kamera wartawan. Gibran pun sering kali menjawab pertanyaan wartawan dengan "Aah, biasa saja" dan cenderung pelit berkomentar di media. Hal-hal inilah yang tentu bertolak belakang ketika menjadi public figure terutama sebagai pejabat publik.

Sebelum mencalonkan diri sebagai Wali Kota Solo, Gibran merupakan pengusaha lokal Solo. Usaha yang dimiliki ada di bidang kuliner. Pada awalnya, Gibran telah merintis usaha katering Chilli Pari sejak tahun 2010 di Solo dan terus berkembang di beberapa kota di Pulau Jawa. Selain katering, Gibran juga membuka gerai martabak yang telah tersebar di seluruh Indonesia. Berbagai usaha di bidang lainnya juga dijalankan bersama dengan sang adik, Kaesang Pangarep, seperti minuman dan restoran. Tidak hanya terus mengembangkan bisnis kulinernya, Gibran juga membuat usaha startup berupa aplikasi untuk menghubungkan pencari kerja paruh waktu atau kerja lepas (Hasibuan, 2019). Dengan pencalonan sebagai Wali Kota Solo, Gibran menyerahkan usaha-usaha yang dimiliki kepada Kaesang untuk dijalankan.

Selama ini Gibran bukan anggota PDIP, namun begitu pada akhir September 2019, secara resmi Gibran mendaftar sebagai anggota partai tersebut sebagai salah satu syarat dalam mencalonkan diri sebagai Wali Kota Solo dari PDIP. Namun begitu, salah satu persyaratan administrasi dalam menjadi bakal calon Kepala Daerah/Wakil Kepala Daerah dari PDIP adalah menjadi anggota partai selama tiga tahun dan telah direkomendasikan oleh pengurus partai dari domisili kandidat tersebut (Detik.com, 2019a). Hal ini masih menunggu keputusan dari DPP PDIP. Pencalonan diri Gibran sebagai Wali Kota Solo dianggap sebagai aji mumpung dan menciptakan dinasti politik. Jabatan yang kini dipegang oleh ayah Gibran sebagai Presiden negara ini mampu membuat Gibran memperoleh popularitas dalam Pilkada. Selain itu, Gibran 
dianggap belum memiliki pengalaman di bidang politik dan baru saja bergabung dalam partai dianggap sebagai tindakan terburu-buru (Azanella, 2019). Akan lebih baik jika Gibran mencalonkan diri setelah tahun 2024 atau ketika berakhirnya periode pemerintahan Presiden Jokowi. Namun begitu, Gibran terus berupaya untuk ikut dalam pencalonan Wali Kota Solo pada Pilkada 2020. Namun begitu, Gibran tetap mencalonkan diri pada Pemilihan ini.

Dengan melihat latar belakang tersebut, maka pertanyaan penelitian ini adalah bagaimana marketing politik yang dilakukan oleh Gibran di media untuk mencalonkan diri sebagai Wali Kota Solo dan pemberitaan terkait pemilihan Gibran tersebut.

\section{METODE PENELITIAN}

Metode yang dilakukan untuk menganalisis strategi yang dilakukan oleh Gibran Rakabuming Raka dalam mengikuti Pilkada 2020 di Kota Solo adalah melalui paradigma konstruktivis. Paradigma ini biasa digunakan pada pendekatan kualitatif dengan mencari pemahaman mengenai dunia tempat manusia tinggal dan bekerja (Creswell, 2014). Crotty (1988) menambahkan paradigma konstruktivis berupaya dalam memaknai dunia yang dikonstruksi oleh manusia (Creswell, 2014). Pendekatan kualitatif menempatkan peneliti pada dunia objek penelitian dengan seperangkat interpretatif, praktik material sehingga dapat terlihat dengan menggunakan catatan, wawancara, percakapan, foto, rekaman dan memo pribadi (Denzin \& Lincoln, 2000) serta dimaksudkan untuk mengeksplorasi dan memahami masalah sosial pada yang ada pada individu maupun kelompok (Creswell, 2014). Pendekatan ini melibatkan interpretatif dengan berusaha memahami atau menafsirkan fenomena yang ada, berupa tindakan, keputusan, nilai dan lain-lain dalam dunia sosial (Snape \& Spencer, 2003). Penggunaan ini digunakan ketika penelitian sosial tidak dapat dihasilkan dalam bentuk data kuantitatif atau berupa angka serta masalah yang ada tidak dapat ditangani oleh penelitian kuantitatif (Bryman, 2012).

Kajian literatur digunakan dalam memperoleh data terkait Pilkada 2020 mengenai marketing politik serta softening news berita Pemilihan Wali Kota Solo. Selain itu, juga pemberitaan melalui media massa sebagai teknik pengumpulan data melalui dokumentasi. Berikut jenis-jenis dokumentasi (Yin, 2003):

- Surat, memorandum dan bentuk komunikasi lainnya

- Agenda, pengumuman, notulen rapat dan laporan tertulis lainnya dari suatu acara

- Dokumentasi administrasi seperti proposal, laporan dan catatan internal

- Studi formal atau evaluasi

- Kliping koran atau artikel lainnya yang ada di media massa atau koran komunitas

Kelebihan dari teknik pengumpulan data dengan dokumentasi adalah lebih stabil dilihat berkali-kali. Selain itu, teknik dokumentasi ini berisikan nama, referensi dan detail yang pasti terhadap suatu peristiwa. Cakupan luas dengan waktu, peristiwa yang lebih beragam dengan berbagai keadaan menjadi kelebihan dari teknik dokumentasi. Namun teknik dokumentasi ini memiliki kelemahan seperti pemilihan yang bias dalam memilih laporan (Yin, 2003). Yin juga menambahkan teknik dokumentasi ini sangat berguna walaupun tidak selalu akurat dan bias. Dengan adanya akses internet, dokumentasi dapat dicari dengan akses

Walaupun dokumen tersebut bukanlah sumber akurat namun dokumen tersebut tetap memiliki fungsi sebagai salah satu sumber pengumpulan data. Penggunaan dokumen adalah untuk menguatkan dan menambah bukti dari sumber lainnya. Pertama, dokumen sangat membantu dalam memverifikasi ejaan dan judul ataupun nama organisasi. Kedua, dokumen memberikan perincian spesifik lainnya untuk menguatkan informasi dari sumber lain. Namun jika bukti yang ditunjukkan dari dokumen malah bertentangan dan bukan menguatkan maka perlunya mencari sumber masalah dengan metode lain. Ketiga, dapat membuat kesimpulan dari dokumen, misalnya dengan mengamati daftar distribusi untuk dokumen tertentu. Namun begitu, pada dokumentasi lebih kepada harus menempatkan kesimpulan hanya sebagai petunjuk yang seharusnya diselidiki lebih lanjut dan bukan sebagai temuan karena kesimpulan bisa jadi petunjuk yang salah (Yin, 2003).

Teknik pengumpulan data yang digunakan lainnya adalah dengan observasi terhadap akun media sosial milik Gibran Rakabuming Raka. Observasi ini juga untuk melihat bagaimana Gibran memanfaatkan media sosial sebagai media yang populer saat ini. Menurut Gorman dan Clayton, studi observasi dilakukan dengan melibatkan rekaman yang dibuat secara sistematis dari suatu fenomena atau perilaku dan dapat diamati dalam suatu lingkungan (Baker, 2006). Becker dan Geer juga menambahkan observasi merupakan kegiatan terselubung atau terbuka di mana pengamat mengamati hal-hal yang terjadi, mendengarkan apa yang dikatakan atau menanyai orang lain dalam jangka waktu tertentu (Baker, 2006). Baker menambahkan untuk melakukan observasi tidak selalu terlibat langsung dengan hadir. Dalam menciptakan observasi yang efektif bergantung kepada apa yang menjadi pemahaman yang mendasari untuk melakukan observasi, mengidentifikasi pertanyaan dengan jelas, bagaimana menentukan tipe observasi yang sesuai, dan kapan waktu yang tepat untuk melakukan observasi (Slack \& Rowley, 2001).

Observasi merupakan merupakan bentuk dari pendekatan pengumpulan data. Beberapa alasan menjelaskan observasi merupakan salah satu metode penting dalam pengumpulan data, yaitu (Slack \& Rowley, 2001): 
- Digunakan dalam mengumpulkan data yang mungkin tidak dapat diakses oleh peneliti.

- Dapat menghasilkan informasi secara langsung dengan mengamati atau berpartisipasi serta dapat membantu dalam mengidentifikasi keterbatasan yang terjadi.

Observasi juga dilakukan dengan melalui suatu teori, latar belakang pengetahuan, asumsi juga perspektif (Garner et al., 2009). Dalam penelitian ini, peran peneliti adalah non partisipan, di mana peneliti hanya dapat mengobservasi dari lingkungan yang berbeda (Baker, 2006).

Menurut Bryman, salah satu cara untuk menganalisis data pada penelitian kualitatif adalah dengan pendekatan analisis induksi (Bryman, 2012). Analisis ini dimulai dengan mencari definisi dari pertanyaan penelitian lalu membuat penjelasan hipotesis untuk kemudian mengumpulkan data yang relevan penelitian. Dalam menentukan data yang relevan terutama diambil dari internet, maka informasi yang dipilih apakah reliabel atau tidak dengan 7 (tujuh) hal berikut (Walliman, 2011):

- Akurasi

- Otoritas yang dimiliki

- Bias dalam pemberitaan

- Detail dari informasi tersebut

- Berita terbaru

- Diperiksa ulang dengan sumber lainnya

- Melakukan pra evaluasi dari sumber tersebut

\section{HASIL DAN PEMBAHASAN}

\section{A. Kajian Konseptual}

\section{Marketing Politik}

Henneberg mendefinisikan marketing politik merupakan perkembangan dari pemasaran komersial (R. Ormrod, 2012). Hasitchka (1995) berpendapat pemasaran politik ditandai dengan adanya interaksi di pasar, antara kandidat atau partai politik dengan pemilih. Hal ini identic dengan adanya pertukaran politik (Henneberg \& Ormrod, 2013). Definisi lain mengenai marketing partai politik adalah strategi yang digunakan dari aktor politik termasuk partai politik dan kandidat untuk menggunakan dan mengembakan strategi mereka untuk mencapai tujuan, memenangkan pemilihan (Henneberg, 2006).

Lees-Marshment menjelaskan marketing politik merupakan cara bagi organisasi politik dalam mengadaptasi konsep dan teknik bisnis marketing dalam meraih tujuan (Lees-Marshment, 2001). Salah satu penelitian yang dilakukan oleh Lees-Marshment menjadi perhatian mengenai marketing politik. Lees-Marshment memperkenalkan konsep Comprehensive Political Marketing (CPM) dengan memperhatikan 5 hal, yaitu (Lees-marshment, 2001):

1. Pandangan CPM terhadap marketing politik lebih menyederhanakan komunikasi politik

2. CPM mengaplikasikan marketing dalam keseluruhan tingkah laku pada organisasi politik

3. CPM menggunakan konsep marketing bukan hanya teknik berupa produk, sales maupun orientasi pasar tetapi juga intelijen pasar, desain produk dan promosi

4. CPM mengintegrasikan literatur dalam ilmu politik dalam menjadi sebuah analisis

5. CPM mengadaptasi teori marketing untuk menyatukan perbedaan dalam politik

Studi CPM digunakan untuk menganalisis pola dari partai politik. Terdapat 3 (tiga) pola pada partai politik yaitu Product Oriented Party (POP), Sales Oriented Party (SOP) dan Market Oriented Party (MOP). Product Oriented Party (POP) mempertahankan yang telah dimiliki dan dipercayai. Partai berasumsi pemilih akan tetap memilih mereka, untuk itu partai ini menolak terhadap perubahan ide maupun produk. Pada tipe ini terdapat lima tahap yaitu:

1. Partai menentukan kebijakannya atau visi misi sebagai desain produk

2. Partai mengkomunikasikan kepada seluruh anggota mengenai kebijakannya.

3. Mengkampanyekan kebijakan partai kepada pemilih

4. Pemilihan

5. Penyampaian kebijakan dalam pemerintahan

Sedangkan Sales Oriented Party (SOP) adalah di mana partai fokus dalam menjual argumen-argumen kepada pemilih. Partai ini telah memiliki desain produk sendiri namun mengetahui ada keinginan yang lain atau berbeda dari pemilih dengan melakukan riset pasar. Riset pasar digunakan untuk memahami respon pemilih, sehingga partai dapat menyesuaikan dalam berkomunikasi dengan pemilih. Pada tipe ini melalui tahapan:

1. Mendesain produk berupa kebijakan terbaik atau visi misi partai sesuai dengan keinginan partai.

2. Melakukan riset pasar untuk mengetahui respon pemilih yang kemungkinan tidak mendukung terhadap 
kebijakan yang dibuat sehingga dapat dikomunikasikan dan menjadi target dari partai

3. Menyampaikan pesan kebijakan partai kepada seluruh anggota

4. Kampanye dilakukan untuk memperoleh dukungan terhadap partai

5. Pemilihan

6. Partai akan menyampaikan kebijakannya dalam pemerintahan

Pola ketiga yaitu Market Oriented Party (MOP). Pola yang mendesain produk atau kebijakan partai sesuai dengan keinginan pemilih. Partai telah melakukan riset pasar untuk mengidentifikasi permintaan pemilih lalu menentukan kebijakan yang sesuai dengan pemilih. Partai tidak berusaha untuk mengubah masyarakat tetapi memberikan yang masyarakat butuhkan dan inginkan. Partai tidak hanya menawarkan yang diinginkan oleh pemilih, tetapi partai memastikan bahwa memberikan kebijakan yang ditawarkan. Pada tipe ini melalui tahap:

1. Melakukan riset pasar untuk mengetahui respon pemilih

2. Mendesain produk atau kebijakan sebagai respon dari keinginan pemilih

3. Penyesuaian desain produk untuk memastikan pesan disampaikan

4. Implementasi produk pada partai

5. Menyampaikan pesan kepada seluruh anggota partai

6. Kampanye dan partai tetap melakukan komunikasi secara efektif

7. Pemilihan

8. Partai akan menyampaikan kebijakannya dalam pemerintahan

Pola dari Lees-Marshment digunakan untuk menganalisis strategi yang dilakukan kandidat dalam memperoleh dukungan.

\section{Softening Jurnalistik pada Komunikasi Politik}

Berita-berita politik saat ini tidak hanya berupa hard news yang seharusnya sebagai bentuk edukasi politik kepada masyarakat. Saat ini, telah terjadi fenomena softening berita politik, di mana berita politik tidak lagi mengutamakan informasi akan suatu berita tetapi kepada hiburan (Otto et al., 2016). Hal ini tidak hanya dilakukan oleh jurnalis media itu sendiri, namun juga oleh para politisi dan para ahli, yang dikenal dengan model kerangka kerja softening komunikasi politik. Terdapat 5 tingkatan/level yaitu: eroding of boundaries, tabloidization, infotainment, soft news dan sensationalism.

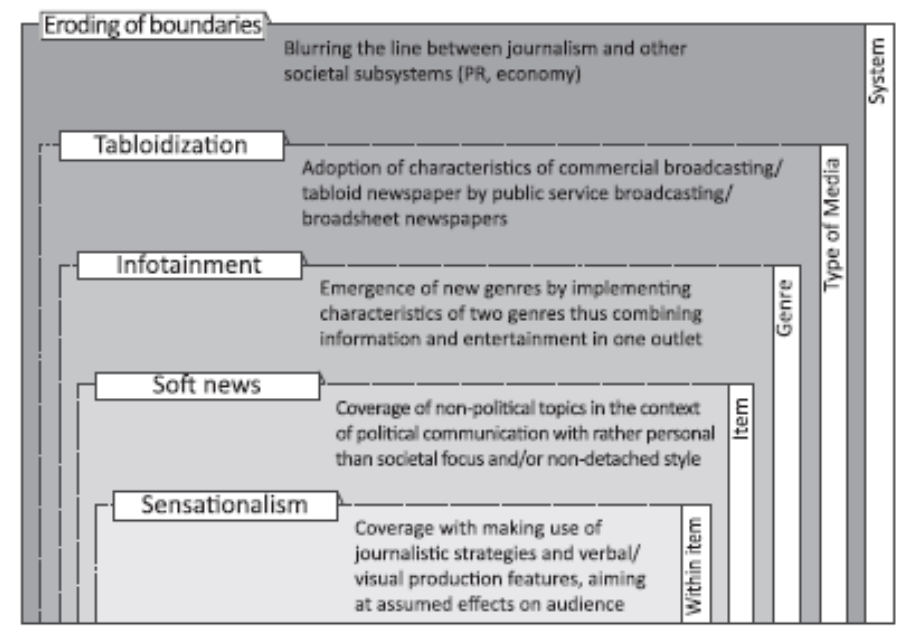

Gambar 1 Model Kerangka Kerja Softening Komunikasi Politik (Otto et al., 2016)

Pada konsep ini terdapat garis putus-putus yang menunjukkan bahwa tiap level pada konsep ini tidak tertutup. Level yang lebih tinggi dapat merangkum yang lebih rendah.

Uribe dan Gunter (2007) menjelaskan sensationalism merupakan proses mengemas berita dengan menekankan elemen-elemen tertentu dengan tujuan untuk memprovokasi efek pada sistem sensor manusia sehingga memperoleh perhatian audiens. Sedangkan soft news merupakan pengemasan informasi non-politik dalam komunikasi politik. Infotainment membuat kaburnya berita antara genre berorientasi pada informasi atau berdasarkan hiburan. Tabloidization adalah perubahan isi serta gaya bahasa berita politik yang disesuaikan dengan penonton atau pembaca. Level terakhir, eroding boundaries membuat kaburnya batasan antara jurnalisme dengan subsistem komunikasi lainnya seperti periklanan atau perhumasan, baik dari sensationalism hingga tabloidization. 


\section{B. Temuan dan Analisis}

\section{Sebelum Pencalonan}

Gibran Rakabuming Raka atau Gibran merupakan putra pertama Presiden Joko Widodo. Dengan statusnya sebagai anak Presiden, tentu hal ini menjadikan Gibran sebagai salah satu sorotan media. Bahkan sejak Jokowi, panggilan akrab Presiden Joko Widodo, mencalonkan diri sebagai Presiden di Pemilihan Presiden 2014, wartawan dari berbagai media berusaha untuk mewawancarai anak Presiden tersebut. Namun, reaksi Gibran di depan media dianggap kaku bahkan seperti sombong. Seringnya Gibran mengangkat dagu dianggap bentuk rasa sombong atau pongah. Gibran jarang tersenyum di media, yang berbeda dengan kedua adiknya. Bahkan ketika diwawancarai oleh wartawan mengenai perasaan ketika sang ayah mencalonkan diri sebagai Presiden dan memenangkan pemilihan, Gibran hampir selalu menjawab, “Ah.. Biasa saja." Pertanyaan dari wartawan juga sering dijawab dengan singkat oleh Gibran terutama yang berkaitan dengan tampilannya di publik atau posisi sang ayah.

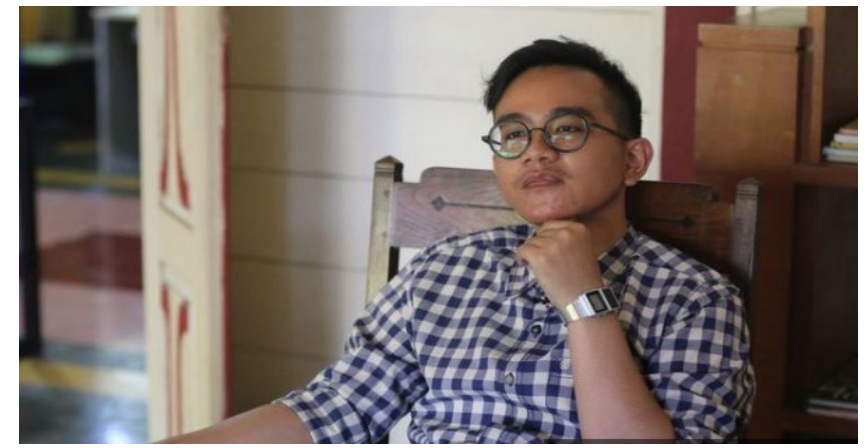

Gambar 2 Gibran Rakabuming Raka.

Sumber: Warta Kota (2017)

Perkembangan media baru, terutama media sosial, juga dimanfaatkan oleh Gibran dalam mempromosikan berbagai usaha yang dimilikinya. Salah satu akun media sosial yang aktif adalah Twitter. Gibran memakai akun(@chilli_pari) untuk mempromosikan bisnisnya. Di akun ini, Gibran pun cukup aktif mengomentari berbagai hal dan menjawab pertanyaan dari pengguna media sosial lainnya. Berbeda jika diwawancarai oleh wartawan, Gibran beberapa kali menjawab sindiran, kritik atau pertanyaan yang ditujukan untuk dirinya maupun ayahnya melalui media sosial. Beberapa isu-isu sosial politik juga menjadi bahan bagi Gibran untuk hanya sekedar memberikan komentar atau sindiran. Namun begitu, berita positif bukan hanya menguntungkan bagi usaha yang dimilikinya, tetapi juga berita negatif yang beredar di media. Berita negatif membantu membesarkan usaha yang dimilikinya (CNN, 2018). Berita negatif yang ia terima adalah hiasan dinding di salah satu gerai Markobar miliknya yang menyebar di media membuat banyak yang datang ke gerainya untuk melihat. Gerakan untuk mengganti Presiden Jokowi dari beberapa kelompok masyarakat dengan gerakan \#2019GantiPresiden juga menjadikan salah satu gerai milik Gibran sebagai tempat kelompok tersebut melakukan unjuk rasa. Melalui akun Twitter lainnya, hal tersebut malah dianggap Gibran sebagai saat tepat untuk mempromosikan bisnisnya di media sosial.

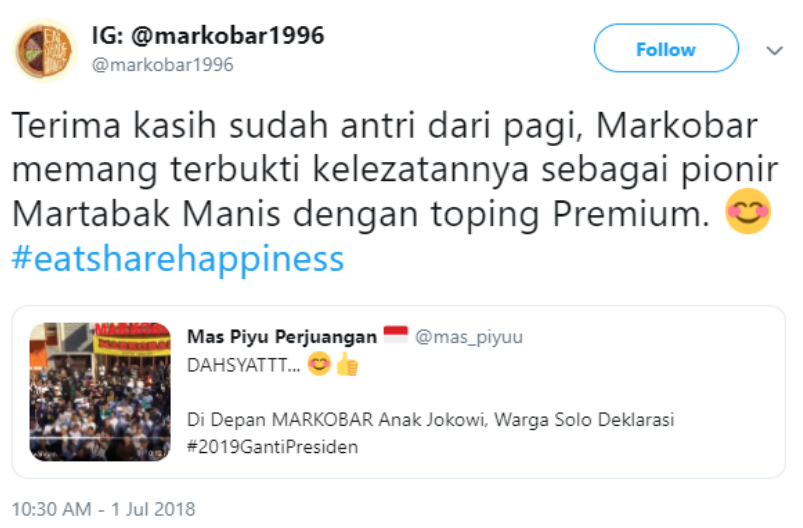

Gambar 3. Tangkapan Layar Twitter Markobar Sumber: Akun Twitter Markobar

\section{Pencalonan sebagai Wali Kota Solo}

Pro dan kontra muncul ketika Gibran mencalonkan diri untuk mengikuti Pilkada 2020 sebagai Wali Kota Solo. Dengan pencalonan dirinya sebagai Wali Kota Solo, beberapa pengamat menilai hal ini dapat menciptakan dinasti politik. Politik aji mumpung juga menjadi hal yang sering diungkapkan di berbagai media mengenai pencalonan ini, mengingat 
sang ayah masih menjabat sebagai Presiden Republik Indonesia untuk kedua kalinya dan Gibran belum memiliki pengalaman politik, bahkan dengan menjadi anggota partai politik. Sejak karir politik Jokowi terus menanjak hingga menjadi Presiden, Gibran tidak menunjukkan ketertarikan untuk terlibat pada politik praktis.

Sejak pencalonan sang ayah hingga menjadi presiden di periode pertama pemerintahannya, Gibran jarang terlihat ikut menemani Jokowi dalam kegiatan politiknya. Hal ini berbeda dengan adik-adik Gibran. Alasannya, karena Gibran sibuk bekerja dengan menjalankan bisnis yang dimilikinya. Di salah satu kesempatan ketika bertemu dengan anak Presiden keenam Republik Indonesia Susilo Bambang Yudhoyono, Agus Harimurti Yudhoyono, Gibran menyatakan tidak ingin ikut campur dunia politik (Detik.com, 2019b). Pertemuan pada Bulan April 2018 itu hanya sekedar silaturahmi. Di waktu yang berbeda, Presiden Jokowi memberikan pendapat mengenai minat politik Gibran. Menurut Jokowi, baik Gibran maupun Kaesang tidak memiliki minat dengan dunia politik. Gibran lebih fokus di bisnis yang dimilikinya saat ini. Hingga wawancara dengan seluruh keluarga Presiden, Gibran mengungkapkan tertarik dengan politik namun untuk terlibat dengan politik praktis membutuhkan waktu yang lebih lama.

Pada Bulan Juli 2019, salah satu Universitas di Solo membuat survei mengenai calon Wali Kota Solo periode 2020-2025. Survei terhadap 766 responden, dua nama anak Presiden Jokowi yaitu Gibran dan Kaesang muncul dari hasil survei tersebut. Terdapat tiga hal yang menjadi penilaian, yaitu popularitas, Gibran memperoleh angka tertinggi sebesar 90 responden bersama dengan Wakil Wali Kota saat ini, Achmad Purnomo. Penilaian berikutnya adalah akseptabilitas, Gibran meraih posisi kedua setelah Purnomo. Elektabilitas sebagai penilaian ketiga, Gibran meraih 13 persen di bawah Purnomo sebesar 38 persen. Gibran pun bertemu dengan Ketua Dewan Pimpinan Cabang (DPC) PDI Perjuangan Solo sekaligus Wali Kota saat ini, FX Rudi Hadyatmo pada pertengahan bulan September 2019. Menurut Rudi pertemuan tersebut hanya menanyakan mekanisme pencalonan dan menjadi anggota PDIP (Detik.com, 2019b).

Gibran pun mendaftarkan diri sebagai anggota Partai Demokrasi Indonesia Perjuangan (PDIP) pada akhir September 2019 dan dibuatkan Kartu Tanda Anggota (KTA) sebagai bukti keanggotaan partai secara resmi. Syarat menjadi bakal calon kepala daerah dari PDIP adalah dengan menjadi anggota partai, yang ditunjukkan dengan adanya KTA. Selain itu, bakal calon juga merupakan hasil rekomendasi dari Dewan Pimpinan Pusat (DPP). Saat ini dari DPP PDIP masih melakukan penyaringan dan penjaringan bakal calon kepala daerah. PDIP melakukan fit and proper test terhadap bakal calon kepala daerah, termasuk Gibran. Tim fit proper test tersebut menanyakan mengenai kesiapan Gibran untuk maju sebagai calon Wali Kota jika terpilih. Dari hasil pertanyaan untuk fit proper test, alasan Gibran ingin menjadi Wali Kota Solo adalah ingin membesarkan PDIP dengan semangat gotong royong pada seluruh elemen partai di Solo (Utama, 2019).

\section{Marketing Politik Gibran di Media pada Pilkada Solo}

Henneberg (2002) mendefinisikan marketing politik dengan mengacu pada marketing komersial yang dijelaskan oleh Gronroos (1990), di mana untuk membangun, memelihara serta memelihara hubungan jangka panjang yang menguntungkan antara kandidat dengan masyarakat dengan saling tukar menukar dan memenuhi janji (Butler et al., 2007), walaupun hubungan tersebut tidak selalu memiliki timbal balik yang seimbang antara kandidat dan pemilih (R. Ormrod, 2012). Marketing politik juga merupakan strategi yang digunakan dari aktor politik termasuk partai politik dan kandidat untuk menggunakan dan mengembangkan strategi mereka untuk mencapai tujuan, yaitu memenangkan pemilihan (Henneberg, 2006). Partai politik maupun kandidat harus dapat mengelola hubungan dengan berbagai stakeholder termasuk dengan media dan pemilih dengan mengidentifikasi tiap stakeholder (R. Ormrod, 2012).

Kesuksesan dari interaksi pemilihan sebagai bagian dari marketing politik adalah apabila kandidat memenangkan pemilihan (R. Ormrod, 2012). Untuk menjadi kepala daerah dan memenangkan pemilihan membuat Gibran harus melakukan perubahan-perubahan terutama dengan cara bersikap di depan media. Media memiliki peran yang penting bagi partai politik maupun kandidat yang mengikuti suatu kontestasi politik. Secara signifikan, media dapat mempengaruhi dan berperan penting dalam perilaku kandidat dan kampanyenya untuk memahami fenomena pertukaran politik (R. P. Ormrod \& Henneberg, 2010). Selama ini, Gibran dianggap sombong dan kaku jika menghadapi wartawan. Hal ini terlihat beberapa foto yang ditangkap kamera wartawan, Gibran sering terlihat jarang tersenyum dan mengangkat dagu, yang dianggap sebagai sosok yang angkuh dan sombong. Namun, sejak masuk dalam bakal calon Wali Kota Solo, Gibran mulai melakukan perubahan tampilan di depan public dan media. Penyesuaian-penyesuaian juga dilakukan oleh Gibran untuk sejalan dengan nilai-nilai yang ada di PDIP. Dekat dengan rakyat merupakan nilai selama ini yang 'dijual' oleh PDIP oleh untuk meraih simpati dari pemilih. Hal ini menunjukkan bagaimana partai politik atau kandidat berperilaku sesuai pemilih (Strömbäck et al., 2012).

Sejak menjadi bakal calon Wali Kota Solo, Gibran pun membuat akun media sosial atas nama dirinya sendiri. Selama ini, Gibran lebih banyak berinteraksi di media sosial melalui media sosial milik usaha bisnisnya, yaitu akun Chilli Pari maupun Markobar. Sama halnya dengan komersial, media sosial saat ini dimanfaatkan di dunia politik, di mana kandidat dapat memanfaatkan media sosial dalam mengarahkan opini public (Safiullah et al., 2017). Media sosial pun dapat digunakan sebagai alat dalam mengekspresikan opini, pandangan, dan ide untuk mempengaruhi (Safiullah et al., 2017). Gibran menyadari peran media sosial dalam pencalonannya. Tertanggal 8 November 2019, Gibran membuat akun Instagram atas nama diri sendiri. Akun Instagram ini berisikan berbagai kegiatan Gibran, termasuk kegiatan politiknya 
dengan melakukan kunjungan untuk bertemu dengan masyarakat atau tokoh politik, seperti Ketua Dewan Perwakilan Rakyat (DPR) RI, Puan Maharani. Sedangkan, berbagai bisnis usaha milik Gibran telah diserahkan kepada adiknya, Kaesang. Namun begitu, Gibran tetap mempromosikan bisnisnya melalui akun Instagram pribadinya ini.

Dalam konsep Comprehensive Political Marketing (CPM) Lees-Marshment terdapat tiga pola partai politik. PDIP dan Gibran merupakan bentuk pola dari Sales Oriented Party (SOP). SOP menjelaskan bagaimana partai politik telah memiliki nilai yang dipercaya oleh partai politik dengan tidak mengubah sesuai keinginan pemilih, tetapi berusaha untuk mengubah apa yang diinginkan pemilih sesuai dengan yang ditawarkan (Lees-Marshment, 2001). Partai dengan pola SOP melakukan market intelligence atau riset pasar untuk mengetahui apa yang diinginkan oleh pemilih. Dekat dengan rakyat menjadi salah satu nilai yang tetap dipertahankan oleh PDIP. Mengingat pada Pilkada DKI Jakarta 2012 dan Pilpres 2014, PDIP memiliki calon kandidat yang belum terlalu dikenal pemilih saat itu yaitu, Joko Widodo. Jokowi memiliki strategi blusukan cukup efektif dalam meraih suara. Blusukan merupakan strategi dari Jokowi agar lebih dekat dengan rakyat dan pemilih. Strategi ini membuat Jokowi meraih suara terbanyak di Pilkada DKI Jakarta 2012 dan Pilpres 2014. Dengan blusukan dan mendatangi pemilih, Jokowi mendengarkan permasalahan yang ada di masyarakat. Hal ini dapat mendekatkan hubungan antara kandidat dengan pemilih.

Hasil survei salah satu lembaga di Solo yang menunjukkan bahwa Gibran merupakan salah satu figur populer saat ini. Hal ini membuat PDIP pun membuka peluang bagi Gibran untuk menjadi bakal calon Wali Kota Solo. Dengan masuknya Gibran sebagai bakal calon Wali Kota Solo, konsep SOP terlihat adanya penyesuaian kandidat, dalam hal ini Gibran, terhadap nilai-nilai yang telah dimiliki partai yang dikenal dekat rakyat dengan kegiatan 'blusukan'. Walaupun dari salah satu syarat menjadi bakal calon kepala daerah dari PDIP adalah telah menjadi anggota partai selama tiga tahun sebagai bentuk proses melalui penjaringan. Namun, PDIP menilai untuk memilih bakal calon kepala daerah juga dapat melihat peta politik. Pemilihan Gibran sebagai bakal calon Wali Kota Solo juga sebagai bentuk komitmen partai untuk mempersiapkan pemimpin muda dan sejalan dengan strategi pemerintahan Presiden Jokowi dengan staf khusus dari generasi muda. Untuk itulah peraturan pencalonan dapat dilihat secara inheren dan komprehensif (Alvetro, 2019). Penentuan pencalonan Kepala Daerah di PDI Perjuangan nantinya menjadi hak dari Ketua PDIP, Megawati Soekarnoputri, dengan melihat calon yang dapat mendukung agenda strategis partai. Hasil ini tergantung dari proses konsolidasi pada Januari 2020.

Selain perubahan sikap sebagai bakal calon kepala daerah dan agar sejalan dengan nilai partai, Gibran menjalankan strategi partai dengan melakukan blusukan untuk bertemu dengan pemilihnya. Hal ini seperti salah satu nilai yang dimiliki oleh PDIP dan pernah dilakukan oleh Jokowi ketika pencalonan dirinya sebagai Gubernur DKI Jakarta di tahun 2012 dan Pemilihan Presiden di tahun 2014. Kegiatan 'blusukan' yang dilakukan Gibran tidak hanya dipublikasikan di akun Instagram miliknya, namun juga di media lainnya, seperti media cetak maupun media online. Wawancara beberapa kali juga dilakukan sebagai bentuk strategi Pilkada 2020 oleh Gibran. Tentunya hal ini sangat berbeda sebelum pencalonan dirinya sebagai bakal calon Wali Kota Solo yang cenderung kaku terhadap media dan wartawan. Walaupun PDIP belum memutuskan bakal calon Wali Kota Solo, Gibran terus melakukan blusukan di Solo untuk menyapa dan mendengarkan permasalahan yang ada di Solo. Dari hasil blusukan, Gibran berencana untuk menggabungkan pasar tradisional dengan e-commerce untuk meningkatkan jumlah pembeli yang datang ke pasar. Gibran juga berencana memperbaiki kondisi kios pasar yang sempit seperti yang dikeluhkan pedagang di Pasar Klewer (Zamani, 2019).

\section{Softening News Gibran di Media}

Pencalonan Gibran sebagai Wali Kota Solo menimbulkan pro dan kontra. Mulai dari pemimpin muda, dinasti politik hingga Gibran dianggap belum mampu karena tidak memiliki pengalaman politik. Dari berbagai pemberitaan negatif dirinya sebagai bakal calon Wali Kota Solo, namun hal ini tidak menyurutkan keinginan Gibran untuk terjun di dunia politik. Hingga secara resmi mendaftarkan diri sebagai bakal calon Wali Kota Solo pada tanggal 12 Desember 2019 , setelah sebelumnya Gibran mendaftarkan diri menjadi anggota PDIP di akhir September 2019. Selain pemberitaan yang cenderung kontra mengenai pro dan kontra pencalonan Gibran, pemberitaan lainnya adalah softening news dari pencalonan ini. Salah satunya adalah mengenai peran dari Ibu Gibran sekaligus Ibu Negara, Iriana Jokowi. Iriana mendukung Gibran untuk mendaftarkan diri sebagai bakal calon Wali Kota Solo. Beberapa media menceritakan bentuk dukungan Iriana kepada Gibran dengan melakukan Sholat Tahajud dan melepas keberangkatan Gibran ke Kantor DPC PDI Perjuangan di Solo. Berita lainnya adalah mengenai Gibran yang bertemu dengan Ketua DPP PDI Perjuangan untuk meminta izin dan petuah dari Megawati kepada Gibran untuk membaca buku Bung Karno (Nurita, 2019).

Pergeseran pemberitaan dari program untuk kepentingan publik menjadi program yang diminati publik juga terjadi pemberitaan pencalonan Gibran. Hal ini hingga menyebabkan sulit menggambarkan media yang relevan secara politis kepada penggunanya (Boukes \& Boomgaarden, 2015). Selain pemberitaan yang cenderung kontra terhadap pencalonan Gibran, pemberitaan di media yang banyak ditemukan adalah mengenai berita softening dengan tipe tabloidization. Tabloidization menekankan 3 aspek, yaitu range di mana perubahan dari isi. Dalam hal ini perubahan dari berita politik menjadi human interest (Otto et al., 2016). Informasi akan strategi yang dilakukan oleh Gibran jika terpilih sebagai Calon Wali Kota Solo, kurang menarik dibandingkan dengan dukungan Ibu Negara terhadap dirinya atau mengenai pertemuan 
dengan buku Bung Karno yang diberikan oleh Ketua Umum PDIP. Aspek kedua adalah perubahan bentuk presentasi dengan berita yang kini ditampilkan lebih pendek dengan lebih banyak menampilkan gambar dan bahasa yang sederhana. Aspek terakhir mode of address di mana penggunaan bahasa disesuaikan dengan pembaca atau penonton (Otto et al., 2016). Hal ini juga dikarenakan adanya pergeseran berita termasuk berita politik di mana berita softening akan lebih menarik public yang lebih luas (Boukes \& Boomgaarden, 2015).

\section{KESIMPULAN}

Walaupun masa jabatan untuk kepala daerah hasil Pilkada serentak keempat kalinya di tahun 2020 kurang dari lima tahun, namun tidak menyurutkan calon kandidat untuk mendaftarkan diri sebagai bakal calon Kepala Daerah. Salah satu bakal calon Kepala Daerah yang cukup menjadi perhatian publik adalah Gibran Rakabuming Raka yang mengikuti Pemilihan Wali Kota Solo. Sebagai anak dari Presiden berkuasa saat ini, pencalonan dirinya sebagai Wali Kota dianggap menciptakan dinasti politik dan aji mumpung. Apalagi selama ini Gibran tidak memiliki ketertarikan dengan dunia politik. Bahkan public appearance Gibran di media dianggap kaku dan sombong yang kurang sesuai jika ia sebagai pejabat publik.

Namun, Gibran tetap mendaftarkan diri sebagai anggota PDI Perjuangan dan menjadikan PDIP sebagai kendaraan politik untuk menjadi bakal calon Wali Kota Solo. Walaupun PDIP belum memutuskan calon Wali Kota Solo, tetapi konsep Sales Oriented Party (SOP) yang diungkapkan Lees-Marshment dijalankan oleh Gibran dalam pencalonan Pilkada 2020 ini. Dari faktor keanggotaan partai, Gibran belum 3 tahun menjadi anggota partai seperti yang disebutkan sebagai prasyarat menjadi kepala daerah dari PDIP. Namun PDIP membuka peluang kepada Gibran dan hal ini juga tidak lepas dari hasil survei yang menunjukkan bahwa Gibran salah satu figur yang populer di Solo. Ditambah lagi kepemimpinan dari generasi muda dianggap inheren dengan strategi Presiden saat ini. Gibran pun mengikuti nilai-nilai dan semangat kerakyatan yang ada di partai dengan membuat strategi blusukan sebagai salah satu strategi yang menonjol dari PDIP. Perubahan Gibran di depan jurnalis dan media mulai terlihat berbeda dengan sebelumnya sebagai salah satu cara untuk menjalankan strategi dalam pencalonannya. Selain itu, Gibran juga menyadari media sosial pribadi juga hal penting untuk mempublikasikan kegiatan politiknya. Sehingga, pemilih dapat mengetahui program kerja Gibran sebagai calon Wali Kota Solo.

Pemberitaan Gibran sebagai bakal calon Wali Kota Solo tidak lepas mengenai pro dan kontra akan hal tersebut. Namun, pemberitaan Gibran lebih banyak kepada berita-berita yang tidak menggambarkan strategi politiknya jika terpilih sebagai calon Wali Kota Solo dari PDIP. Berita-berita softening dengan tipe tabloidization lebih banyak ditemukan di media-media online dibandingkan dan pemilih mengetahui program kerja Gibran untuk menjadi Wali Kota. Edukasi politik kepada pemilih menjadi semakin menurun dengan banyak berita yang bersifat softening news.

\section{DAFTAR PUSTAKA}

[1] Alvetro, Y. (2019). Gibran Terganjal Syarat 3 Tahun Kader, PDIP: Bu Mega Berhak Menetapkan. https://news. detik.com/berita/d-4833250/gibran-terganjal-syarat-3-tahun-kader-pdip-bu-mega-berhak-menetapkan

[2] Azanella, L. A. (2019). Pro-kontra Iringi Niat Gibran Rakabuming Maju Pikada Solo - Kompas.com. https://www. kompas.com/tren/read/2019/12/08/193000065/pro-kontra-iringi-niat-gibran-rakabuming-maju-pikada-solo?page=all

[3] Baker, L. M. (2006). Observation: A Complex Research Method. Library Trends, 55. https://www.webpages.uidaho. edu/CSS506/Technique Readings/Baker 2006 Observation a complex research method.pdf

[4] Boukes, M., \& Boomgaarden, H. G. (2015). Soft News With Hard Consequences? Introducing a Nuanced Measure of Soft Versus Hard News Exposure and Its Relationship With Political Cynicism. Communication Research, 42(5), 701-731. https://doi.org/10.1177/0093650214537520

[5] Bryman, A. (2012). Social Research Methods (4th ed.). Oxford.

[6] Butler, P., Collins, N., \& Fellenz, M. R. (2007). Theory-Building in Political Marketing. Journal of Political Marketing, 6(2-3), 91-107. https://doi.org/10.1300/j199v06n02_06

[7] CNN. (2018). Keluarga Jokowi Anggap Berita Negatif Menguntungkan. https://www.cnnindonesia.com/nasion al/20181208131521-32-352084/keluarga-jokowi-anggap-berita-negatif-menguntungkan

[8] CNN. (2019). Purnomo Tak Gentar Bersaing dengan Gibran Jadi Cawalkot Solo. https://www.cnnindonesia.com/ nasional/20191221125613-32-458946/purnomo-tak-gentar-bersaing-dengan-gibran-jadi-cawalkot-solo

[9] Creswell, J. W. (2014). Research Design: Qualitative, Quantitative and Mixed Method Approaches (4th ed.). Sage Publications.

[10] Denzin, N. K., \& Lincoln, Y. S. (2000). The Discipline and Practice Qualitative Research. In N. K. Denzin \& Y. S. Lincoln (Eds.), The Sage Handbook of Qualitative Research (3rd ed.). Sage Publications.

[11] Detik.com. (2019a). Aturan Maju Pilkada via PDIP Harus 3 Tahun Jadi Kader, Ini Kata Rudy. https://news.detik. com/berita-jawa-tengah/d-4826415/aturan-maju-pilkada-via-pdip-harus-3-tahun-jadi-kader-ini-kata-rudy 
[12] Detik.com. (2019b). Tentang Gibran Rakabuming yang Dulu Ogah Politik, Kini Daftar Jadi Kader PDIP. https:// news.detik.com/berita/d-4718246/tentang-gibran-rakabuming-yang-dulu-ogah-politik-kini-daftar-jadi-kader$\operatorname{pdip} / 1$

[13] Detik.com. (2019). Ini 270 Daerah yang Gelar Pilkada Serentak 2020. https://news.detik.com/berita/d-4596501/ ini-270-daerah-yang-gelar-pilkada-serentak-2020

[14] Ferri, O. (2015). KPU Resmikan Pelaksanaan Pilkada Serentak 2015 - News Liputan6.com. https://www.liputan6. $\mathrm{com} /$ news/read/2215484/kpu-resmikan-pelaksanaan-pilkada-serentak-2015

[15] Garner, M., Wagner, C., \& Kawulich, B. (Eds.). (2009). Teaching Research Methods in the Social Sciences. British Library Cataloguing.

[16] Hasibuan, L. (2019). Anak Jokowi Daftar Walkot Solo, Ini Deretan Bisnis Gibran. https://www.cnbcindonesia.com/ entrepreneur/20191004211245-25-104608/anak-jokowi-daftar-walkot-solo-ini-deretan-bisnis-gibran

[17] Henneberg, S. (2006). Leading or Following A Theoretical Analysis of Political Marketing Postures. Journal of Political Marketing, 5(3), 29-46. https://doi.org/10.1300/J199v05n03

[18] Henneberg, S., \& Ormrod, R. P. (2013). The triadic interaction model of political marketing exchange. Marketing Theory, 13(1), 87-103. https://doi.org/10.1177/1470593112467269

[19] Kemendagri. (2019). Pilkada Serentak Digelar 23 September 2020, Ini Tahapannya! https://otda.kemendagri.go.id/ berita-dan-informasi/pilkada-serentak-digelar-23-september-2020-ini-tahapannya/

[20] Lees-Marshment, J. (2001). The Product, Sales and Market-Oriented Party. 35(9), 1074-1084.

[21] Lees-Marshment, J. (2001). The marriage of politics and marketing. Political Studies, 49(4), 692-713. https://doi. org/10.1111/1467-9248.00337

[22] Nurita, D. (2019). Buku Bung Karno Sampai Doa Iriana Jokowi. Restu untuk Gibran? https://nasional.tempo.co/ $\mathrm{read} / 1284985 /$ buku-bung-karno-sampai-doa-iriana-jokowi-restu-untuk-gibran

[23] Ormrod, R. (2012). Defining Political Marketing. Management Working Papers, 2, 9-21. https://doi. org/10.4135/9781473914827.n2

[24] Ormrod, R. P., \& Henneberg, S. (2010). Understanding voter orientation in the context of political market orientation: Is the political customer king? Journal of Marketing Management, 26(1-2), 108-130. https://doi. org/10.1080/02672570903574270

[25] Otto, L., Glogger, I., \& Boukes, M. (2016). The Softening of Journalistic Political Communication: A Comprehensive Framework Model of Sensationalism, Soft News, Infotainment, and Tabloidization. Communication Theory, 27(2), 136-155. https://doi.org/10.1111/comt.12102

[26] Peraturan KPU No 15 Tahun 2019, (2019).

[27] Peraturan Komisi Pemilihan Umum No. 5 Tahun 2020, (2020).

[28] Safiullah, M., Pathak, P., Singh, S., \& Anshul, A. (2017). Social media as an upcoming tool for political marketing effectiveness. Asia Pacific Management Review, 22(1), 10-15. https://doi.org/10.1016/j.apmrv.2016.10.007

[29] Slack, F., \& Rowley, J. (2001). Observation: Perspectives on research methodologies for leisure managers. Management Research News, 24(1-2), 35-42. https://doi.org/10.1108/01409170110782496

[30] Snape, D., \& Spencer, L. (2003). The Foundation of Qualitative Research. In J. Ritchie \& J. Lewis (Eds.), Qualitative Research Practice: A Guide for Social Science Students and Researchers (p. 379). Sage Publications.

[31] Strömbäck, J., Lees-Marshment, J., \& Rudd, C. (2012). Political party market orientation in a global perspective. Routledge Handbook of Political Marketing, December 2016, 79-92. https://doi.org/10.4324/9780203349908-15

[32] Uribe, Rodrigo \& Gunter, Barrie. (2007). Are 'Sensational' News Stories More Likely to Trigger Viewers'Emotions than Non-Sensational News Stories? A Content Analysis of British TV News. European Journal of Communication. 22. DOI: $10.1177 / 0267323107076770$

[33] Utama, D. A. (2019). Tim Fit and Proper Test PDIP Tanya Strategi Gibran Majukan Solo. https://www.merdeka. com/politik/tim-fit-and-proper-test-pdip-tanya-strategi-gibran-majukan-solo.html

[34] Walliman, N. (2011). Research Methods: The Basics. Routledge.

[35] Warta Kota. (2017) Warta Kota Tribun News. https://wartakota.tribunnews.com/2019/05/26/artikel-dari-lamanjanethescom-gibran-rakabuming-mendidik-anak-untuk-belajar-menerima-kekalahan?page=all

[36] Yin, R. K. (2003). Case Study Research: Designs and Methods. In Qualitative Research (p. 180). https://www. researchgate.net/publication/317953485_Case_study_research_design_and_methods

[37] Zamani, L. (2019). Blusukan ke Pasar Klewer, Gibran Nilai Perlu Ada Perluasan. https://nasional.kompas.com/ $\mathrm{read} / 2019 / 12 / 23 / 19482581 /$ blusukan-ke-pasar-klewer-gibran-nilai-perlu-ada-perluasan. 